tion of their subject matter (monasticism, for example, is discussed at length in both chapters), their chronological limits, and their relation to the main body of the book. In contrast, another analytical chapter on the Monophysite kingdoms (Nubia, Ethiopia, Armenia), which is placed very appropriately between the reigns of Justinian and Heraclius, provides a useful and original introduction to a subject of great difficulty, and profits from the author's long-standing association with the excavations at $Q$ 'asr Ibrim in Nubia.

Narrative, analysis, and documentation are highly satisfactory, and the book is interestingly written. Some of the main personalities of the Monophysite movement, such as Severus of Antioch, receive full biographical treatment; in other cases more information would have been both desirable and available (John of Tella, Ahoudemmeh, and James Bar 'Adai). The book contains some scattered information but no systematic treatment of the institutions of the Monophysite church (episcopate, monasteries, canon law, etc.). Readers of the Slavic Review will regret that works written in Slavic languages, such as A. Diakonov's book on John of Ephesus and N. Pigulevskaia's publications (some of the latter are translated into German), were inaccessible to the author. For the early sixth century, however, this deficiency is partially remedied by the use of Vasiliev's Justin the First, written in English but making full use of the Slavic bibliography. Occasional obscurities such as the puzzling references to provincial councils under Maximin Daia (p. 161), in the sense of secular administrative bodies but within an ecclesiastical context, should have been caught by the editors of Cambridge University Press. In general, the publisher could have done more for this important and useful book. Two sketch maps, for example, are buried in the text and not listed in the table of contents. They record only a fraction of the more important place names mentioned in the narrative, and are rendered confusing by blank spaces left in the middle to accommodate the bookbinder. All of this is especially regrettable in view of the exorbitant price, which puts the book beyond the reach of most persons.

Paul J. Alexander University of California, Berkeley

A NESTORIAN COLLECTION OF CHRISTOLOGICAL TEXTS. Edited and translated by Luise Abramowski and Alan E. Goodman. Vol. 1: SYRIAC TEXT. viii, 223 pp. Vol. 2: INTRODUCTION, TRANSLATION, AND INDEXES. liv, 144 pp. Cambridge University Library Ms. Oriental 1319. University of Cambridge Oriental Publications, nos. 18 and 19. London and New York: Cambridge University Press, 1972. $\$ 12.50$ each.

When the Reverend D. Jenks was working in Urmia, in Persia, at the end of the last century, he acquired a Syriac manuscript which is now in the Cambridge University Library. The manuscript is a nineteenth-century copy of an earlier one, which was made in the thirteenth or fourteenth century. The first volume of the work by Professor Abramowski and $\mathrm{Mr}$. Goodman contains a photographic reproduction of the manuscript, together with an apparatus criticus, which makes use of several other authorities. The reproduction is clear-sometimes clearer than the manuscript itself-and the photographers responsible are to be congratulated for their careful work.

The second volume contains an introduction and a translation of the manu- 
script. The manuscript is described, and the history of the document reproduced in it is discussed. It is suggested that the work was compiled sometime between the eighth and fourteenth centuries, probably in the earlier part of that period, perhaps early in the ninth century. That work, however, incorporated an earlier collection, which contains extracts from no writer later than the seventh century, and "it may already have been in existence at the time" (p. xviii). The introduction also discusses the intention of the compiler in his polemic against Monophysites and supporters of the Council of Chalcedon, and his collection of a number of extracts from Nestorian writers on Christological subjects. There are also discussions of the text of the Bible used in the extracts, and there are indexes of biblical and other quotations, of subjects, and of names.

The editors have given us a careful and scholarly edition, and their judgments are usually convincing. Their translation also maintains a high scholarly standard, notwithstanding a few places where another opinion is possible. The style is sometimes rather Germanic for English taste, but this is a negligible defect from the scholarly point of view. The editors have earned the gratitude of students of Syriac, and also students of church history and Christian doctrine, by their labors.

J. A. EMERTON

Cambridge, England

\section{PSALTERIUM SINAITICUM: AN 11TH CENTURY GLAGOLITIC MANU- SCRIPT FROM ST. CATHERINE'S MONASTERY, MT. SINAI. Edited by Moshe Altbauer. Skopje: Macedonian Academy of Sciences and Arts, 1971. xvi, $360 \mathrm{pp}$.}

Among the 3,300 manuscripts held in the library of the monastery of Saint Catherine on the Sinai, there are 47 Old Church Slavonic manuscripts brought to the Sinai as a gift by priests and pilgrims from Slavic regions. The most ancient of these Old Slavic manuscripts are the Psalterium Sinaiticum and the Euchologium Sinaiticum, both closely related in time, both of Macedonian provenience, and both written in Glagolitic letters. Whereas the Euchologium has been accessible in a photostatic copy for several decades (it was published in 1941 by the Slovenian scholar R. Nahtigal), only two Cyrillic transliterations exist of the Glagolitic Psalterium, the oldest preserved Slavic translation of the Psalms. The first of these transliterations was made in 1883 by L. Geitler under rather unfavorable conditions in Saint Catherine's itself. The second, prepared by the Russian scholar S. N. Severianov, was based on photographs made in 1907 by the Russian Byzantium explorer, V. N. Beneshevich. In 1918 Severianov died without having finished the edition. It was E. F. Karsky who took care of Severianov's work, provided it with a preface, and published it in 1922.

Neither of the Cyrillic transliterations can be considered a substitute for the Glagolitic original, and many of the false conclusions and erroneous interpretations may be ascribed to the inadequate rendering of the original text. This obvious gap in scholarship stimulated Professor Moshe Altbauer, of the Hebrew University in Jerusalem, to make accessible a photostatic edition of the original Glagolitic text of the Psalter. He was assisted by the research committee of his university as well as the Macedonian Academy of Sciences and Arts in Skopje. The new edition has been provided with a thorough English introduction giving a meticulous description of the manuscripts and their graphic and decorative systems. It includes 